\title{
Never Before Seen in Brazil: Luis Inácio Lula da Silva's grand diplomacy
}

Nunca antes visto no Brasil: a grande diplomacia de Lula

PAULO ROBERTO DE ALMEIDA*

Rev. Bras. Polít. Int. 53 (2): 160-177 [2010]

\section{South America was not enough: Luis Inácio Lula da Silva goes out into the world}

Has Brazil already attained the status of a global power, as sought by Luis Inácio Lula da Silva's diplomacy? Or, despite all his efforts, does it remain a mere regional power? Those two questions were, almost obsessively, at the center of Lula's entrepreneurial diplomacy, for the whole duration of his administration (2003-2010). The questions are still open.

Global power status, as is well known, is not a matter of national choice, or an issue subjected only to the political will of the actors involved in what is a complex and interrelated equation. It depends on a complete set of objective factors - connected with economic strength, technological endowments and military capabilities - as well as on a clear recognition of that status by other actors, first of all by the general consensus of the international community, but especially by the great powers. ${ }^{1}$ This recognition is usually linked to primary sources of power - Russia and China clearly fit the pattern - but it can also be associated with other attributions and types of participation in world affairs cooperation, defense of human rights and democracy, etc.

According to those criteria, Brazil cannot be recognized, yet, as a global power, as it lacks some of the capabilities linked to those pre-conditions, with an emphasis on financial and military capabilities. Neither is it acknowledged as such by the world community. Much of the talk about Brazil's new role is due to its active diplomacy under Luis Inácio Lula da Silva, together with the deployment

\footnotetext{
* PhD in Social Sciences and Brazilian career diplomat (pralmeida@me.com).

1 Some of the questions debated in this essay have been already dealt with in other articles by the author, namely: "Brazil in the world context, at the first decade of the $21^{\text {st }}$ century: regional leadership and strategies for its integration into the world economy", In: Joam Evans (org.), Brazilian Defense Policies: Current Trends and Regional Implications (London: Dunkling Books, 2009), p. 11-26; "Lula's Foreign Policy: Regional and Global Strategies", In: Werner Baer and Joseph Love (eds.), Brazil under Lula (New York: Palgrave-Macmillan, 2009), p. 167-183; "Política exterior: potencia regional o actor global", In: "Brasil Emerge", Vanguardia Dossier (Barcelona: La Vanguardia, n. 36, Jul-Sept., 2010), p. 68-72.
} 
of external cooperation towards poor countries in Africa and Latin America (efforts labeled, by the President himself, as the 'diplomacy of generosity'). But, Brazil's association with some less commendable actors - such as Iran or Cuba - as well as its poor record on human rights questions, an issue which clearly diminished in importance in Lula's time, has weakened its credentials in terms of the expectations of public opinion.

But even on a more limited regional basis, it is also probably an exaggeration to count Brazil as a South American 'natural leader', for reasons other than a desire for 'grandeur'. Notwithstanding the fact that it fills almost completely the objective criteria to be recognized as such - territorial, economic and demographic dimensions; size of internal markets; presence in external markets; concentration and diversification of investments; level of industrial development; the most advanced technological basis on the continent; its already large direct investment flows in neighboring countries; and, of course, military capabilities - Brazil does not yet enjoy some of the 'subjective' criteria linked to that status, the most important of those being the willing acceptance by the neighboring countries of such a role. Not only Argentina and Colombia, the two other middle-level powers in South America, but also the smaller countries, are not yet ready to accept Brazil as their regional representative or want it to act as a kind of an unelected speaker on their behalf. Unfortunately, big countries are seldom appreciated in their regions.

This lack of natural leadership derives not only from historical reasons the fact that Brazil is the sole Portuguese-speaking country within a Spanish environment, and that it emerged as a monarchy in the $19^{\text {th }}$ century, in a republican continent - but also from negative contemporary factors, such as the traditional links it has maintained with developed countries in Europe and North America at the expense of its interactions with South American neighbors. Huge Brazilian direct investments and many diplomatic initiatives have been undertaken in recent years in practically all South American countries, but this has not been enough to change the lack of enthusiasm for Brazil's role as a leader.

Notwithstanding its importance in the regional context and its growing role and presence in some questions on the international agenda - especially in multilateral trade policies and WTO negotiations, and environmental affairs, among others - it would be a little premature to count Brazil among the major powers in the world. An objective evaluation of Brazil's current limited capabilities also has to recognize brilliant prospects for the medium term: Brazil is already an 'emerged' country, but still an 'emerging' economy and a power broker. The fact of the general discussion about its greater role on the world diplomatic agenda should be acknowledged as a real accomplishment for President Luis Inácio Lula da Silva.

Any assessment of his diplomacy has to start from the fact - and this is its distinctive character - that it does not follow the traditional patterns of 
professional diplomatic practices, but rather its own Workers' Party, the PT's, ideological choices and political inputs. Those party preferences have left their marks heavily in the foreign policy of Brazil in a manner never seen before 2003. Accordingly, we shall first review the said 'innovation' in Brazilian foreign policy, both in terms of doctrine and of political orientation, and then move to the main issues of the diplomatic agenda. Lula's diplomacy was not only conceived and applied more in line with party politics than with State considerations, but it has also served much more his own motivations for personal aggrandizement in world scenarios than Brazil's national interests.

\section{Shoes and sovereignty: the rhetoric of a sectarian Party diplomacy}

For the first time in decades, or ever, Brazilian foreign policy was conceived and conducted under the overriding influence of non-professional diplomats. The PT's 'foreign policy' was the dominant element in Brazilian foreign policy since the beginning of the da Silva government, but not in a structured manner, as the PT never 'produced' a structured or a complete set of conceptions and solutions for Brazil's international relations. The party always had a poor theoretical structure, simply relying on 'Gramscian' figures from academia for the preparation of more sophisticated papers and proposals relating to economics and political life. But the core of its 'thinking' - if one can indulge it with such a description - is a confused mixture of typical (and stereotypical) Latin-American leftism with old-style nationalism and anti-imperialism, with brushes of Castroism, Stalinism, Trotskyism, and Liberation Theology beliefs.

From the standpoint of its organizational structures, the PT is a quasiBolshevik party, albeit without the old apparatchik apparatus of a Soviet-style Communist party. In the beginning, its core staff was formed mainly by: (a) 'alternative' trade-unionists, who started by rejecting the traditional trade-unions linked to the Ministry of Labor, but who have quickly adapted to the flow of easy money provided by the compulsory labor tax (the act of creating new trade unions is a prosperous 'industry', and the practice has enormously prospered under Lula); (b) old guerrilla-fighters, or semi-professional revolutionaries, 'recycled' into party politics (albeit keeping some old habits from their previous clandestine life, and liaisons with Cuba in particular); and, (c) religious movements, such as the leftist Liberation Theology and 'ecclesial communities'.

The PT's 'ideology' is a mixture of old style socialist credo, prior to the fall of Berlin wall, and of social-democratic economic beliefs (mostly of a purely redistributive character). In fact, many of the sects that make up PT are still true believers in socialism, and are die-hard statists who still trust in the merits of a planned economy. For all purposes, they are anti-capitalists, anti-imperialists, and naturally, anti-Americans, as almost all of the leftist Latin-American parties are. Some of the PT apparatchiks were trained and instructed by Cuban intelligence 
officers, which can explain their loyalty to Cuba's goals in Latin America, such as the organization of the São Paulo Forum (the FSP), a Cuban-sponsored coordinating mechanism for all leftist parties in the region which until 2005 included members of the Colombian FARC. ${ }^{2}$

The PT's main guidelines in foreign policy were established by those involved in its 'international relations', starting with the who had apparatchiks that lived in exile during the military regime (1964-1985). Some of them happened to enjoy the confidence of their Cuban mentors, a fact that exerted some influence in the definition and implementation of 'their' foreign policy, when the time arrived. The future President himself - who, as a trade unionist and leader of metalworkers, developed links with counterparts in Cuba, in the USA, and in Europe - came to understand better the intricacies of international politics; his qualitative leap, the one that was decisive for his own personal life and for the political itinerary of Brazil, was to create in 1980, with the help of former guerrilla fighters, a political party that was to represent a departure from traditional politics and trade-unionism in Brazil.

Nevertheless, the PT always was, and continues to be, a consortium of leftists, engaged actively in the party's cause, which is not exactly a national cause according to the normal lines of a parliamentary or even a presidential democracy. The PT has always relied on mass politics or popular organizations, like students' associations, labor unions or peasant movements, which it controlled. Its concept of democracy is merely instrumental: everything that serves the major objective of holding power for the party fits its "philosophy" and practices. Adhering to a 'Cuban' agenda, it is not surprising if human rights or democracy do not occupy higher levels in this kind of diplomacy. This feature has to be considered as the major political component of Brazilian foreign policy during Luis Inácio Lula da Silva's government.

\section{Bizarre friendships and 'new trade geography': Luis Inácio Lula da Silva's international policy}

Two main objectives have marked, in a somewhat contradictory manner, Brazilian foreign policy under Luis Inácio Lula da Silva: the preservation of national sovereignty and the strengthening of regional integration in South America, the latter being a continuation of policies already implemented by previous governments. The former, that is, the sovereign presence of Brazil in the world, would have to be decreased if the latter is to be reinforced, as exclusively national policies - in sectors such as industry, agriculture, or even trade policy have to accommodate the choices being made in favor of regional integration. Its

2 Minutes of the regular meetings of the FSP, since its foundation, in 1990, up to 2007, with evidence of the participation of the Colombian narco-terrorist group FARC, can be found at this website: http://www. midiasemmascara.org/arquivo/atas-do-foro-de-sao-paulo/7.html, accessed on $20^{\text {th }}$ October 2010. 
priorities were established in three main areas: the reform of the United Nations Charter and Brazil's accession to a permanent seat on its Security Council; the finalization of multilateral trade negotiations, with a preferential option for the relationship with the European Union, instead of the conclusion of the American project of a hemispheric free trade area (FTAA), strongly opposed by the PT and other leftist movements; the reinforcement of Mercosur and its extension to other countries in South America, starting with Chile and other Southern Cone countries, such as Bolivia. Other priorities comprised the establishment of a strong relationship with selected 'strategic allies', designated as being 'nonhegemonic countries', namely China, Russia, India, and South Africa, the last two forming part of the IBSA forum, the first three organized along the lines proposed in the Goldman Sachs study on the BRIC countries.

All these moves followed the so-called 'South-South' diplomacy and the desire to create a 'new geography of world trade' and strengthen the 'democratization of international relations', without 'imperial arrogance' and 'hegemonic unilateralism'. In terms of 'tools' to accomplish those objectives, it is not difficult to recognize the high quality of Brazilian professional diplomacy. Brazil's 'diplomatic GDP' is greater than its economic GDP, and the latter is certainly greater than its 'military GDP', in other words, its capacity for projecting power abroad. Indeed, Brazil's influence in diplomatic negotiations is more important than its actual presence in the world, as compared, for instance, to its participation in trade and financial flows (as a recipient of foreign capital and know-how, and a modest investor abroad). Brazil's professional diplomatic skills make it a relevant actor and sometimes a broker in important multilateral trade negotiations (despite its minor role in financial or trade areas).

Nevertheless, Brazil's influence in the new global interdependence is being handicapped by its mixed feelings toward globalization, and this is reinforced by the PT's leading role in its diplomacy, as the party combines an old-style nationalism with defensive policies in the industrial and investment sectors, including trade protectionism and the promotion of substitutive industrialization. For many of its political leaders - and obviously for all the leftists in the da Silva government - globalization is just another name for Americanization, which they reject and even despise because of their superficial nationalism and instinctive protectionism. It is true that Brazil, in promoting Mercosur, has abandoned the worst aspects of its hard-core protectionism from the 1950s up to the 1980s, but entrepreneurs and the political elite maintain the same old feelings of the 'dependency school', a mixture of developmental Keynesianism and a vague Third World ideology demanding a 'new international economic order'.

Policy reforms, in line with the Washington Consensus of the 1990s, and the Cardoso administration's more receptive attitude toward globalization, brought Brazil more in line with mainstream economics, promoting economic opening and trade liberalization. But, starting with Luis Inácio Lula da Silva’s 
government, those policies were somewhat reversed, if not taken back to the old days of Latin American 'Structuralism', identified with Raul Prebisch and Celso Furtado, former guardians of this 'heterodox' school. This reversal in diplomatic guidelines was presented as a renewal with the 'Independent Foreign Policy' of the early 1960s, when it was in fact only the result of nostalgia for old times.

Many of the new manifestations of this 'sovereign diplomacy' have been focused in consolidating alliances with a few selected partners in the Third World, mainly large emerging countries, notably India, South Africa and China, with the addition of Russia to the process, as it is considered to be an 'anti-hegemonic' counter-power. Great efforts have been made to achieve the goal of inserting Brazil into the inner sanctum of the UN Security Council, an initiative that served to arouse the opposition of Argentina and other competitors. Another goal, that of strengthening and expanding Mercosur, with the inclusion of new partners in South America has, in fact, resulted in the dilution of its trade rules and in an overextension of 'social pacts', which have little meaning for real integration.

In parallel with the so-called 'diplomacy of generosity' in Latin America - to consolidate a self-ascribed 'Brazilian leadership' in the region, a role always rejected by professional diplomacy, mindful of its negative tones - the PT government took initiatives to isolate United States in the region and enlarge the sphere of selfcoordination among Latin American or South American countries. It started by refusing - in fact sabotaging - the FTAA initiative, proposed by President Clinton in 1994, an act undertaken by a joint action by Argentina, Brazil and Venezuela. This policy was also pursued through a series of proposals for the establishment of new bodies uniting exclusively South or Latin American countries. One of them was aimed at submitting the Colombian-US agreement for cooperation against the narco-guerrillas to a detailed scrutiny by a new consultation mechanism proposed by Brazil: the South American Defense Council, itself part of a larger structure, the Union of South American Nations (Unasur).

In February 2010, for instance, with total support from Brazil, a Latin American 'unity' Summit decided the double establishment of the new Community of Latin American and Caribbean States, which replaced the former Rio Group (1986), and of a Latin American Summit on Integration and Development, also created by a Brazilian initiative in December 2008. "For the first time in 200 years", it was said, Latin American countries were meeting "without any kind of guardianship", that is, exempt from any influence from the 'empire' and fully integrating Cuba into the coordinating and consultation mechanisms. The exclusion of the 'empire' was presented as a "success", a 'first' in Latin American history, as Brazilian diplomacy acquired the capacity to "say no".

The anti-American orientation of those actions was very clear, not only for ideological reasons, a feature which might be normally expected from a typical leftist Latin American party, such as PT, still proud of its Cuban links and its solidarity with 'liberation movements'. It was also welcomed as a misguided 
feeling that integration under the aegis of "imperialism of free-trade" (as the American initiatives were labeled) would rather correspond to a project of 'annexation', instead of a symmetrical integration. It was on behalf of that creed that many other initiatives were taken, including the deliberate sinking of the regional negotiations for a hemispheric free trade area and the frustrated proposal for a South American free trade area (which did not prevent some countries from signing bilateral trade agreements with the US).

Paradoxically, Brazil was accused of being 'imperialist', and has been asked, in consequence, to pay the costs of the 'asymmetrical situation' created by its very huge presence. Bolivia, Paraguay, Uruguay, other countries - even Argentina - forced Brazil to accept new and very generous terms for the reinforcement of their relationship: Bolivia nationalized oil and gas resources exploited by the Brazilian state company Petrobras; Paraguay required additional payments for its share of electricity generated by the bi-national hydro-electric plant at Itaipu; Argentina unilaterally imposed safeguards and other defensive trade restrictions on a number of Brazilian manufactured goods that would be normally exported through the free-trade area of Mercosur; Uruguay and other countries, including Venezuela wanted investments or financing from Brazil.

During previous administrations, professional diplomacy conducted bilateral relations with the United States under normal assumptions of cooperation and consultation without any ideological misconceptions about what is usually called 'American hegemonic pretensions'. The PT's diplomacy reverted to the 'normal' anti-imperialism (together with some anti-Americanism) of the old Latin American left. Dealing cautiously with American interests in the world and in the region during its first mandate, the da Silva government exhibited a more assertive 'anti-hegemonic' stance in its second mandate, developing (at least rhetorically) some confrontational positions in relation to American interests in the global scenario; political conflicts over specific issues were always avoided and direct opposition never allowed to arise, but a more assertive behavior, connecting Brazil with other 'non-hegemonic' emerging powers, was allowed to develop (in fact, was explicitly promoted).

\section{Too much transpiration, less inspiration: Luis Inácio Lula da Silva's diplomacy in action}

Intentions and proclamations aside, diplomacy under Luis Inácio Lula da Silva has to be evaluated according to its concrete results - or lack thereof in the many subjects that mobilized the attention of the professional staff of the Foreign Service, under the triple guidance of the Presidential Assistant, the Minister and his Secretary-General, with the clear approval and the appreciation of the President himself. Among those issues, the following protracted the most attention from all these actors during the period under consideration: the UN 
Security Council; alliances with strategic partners; Mercosur and related issues of regional integration; the relationship with Argentina; Brazil's leadership in South America and regional blocs; the WTO and multilateral trade negotiations; relations with other emerging powers and the international role of Brazil. For some of these issues, the PT already had its own 'policies'; for others, it followed the official diplomatic line, distorting it for its own purposes.

\section{The United Nations Security Council: a long-standing obsession}

Despite a vague mention related to the "reform of international organizations", the issue was never a priority in the PT's guidelines on Foreign Policy but it was a pet subject for the Foreign Minister, who had a long career in multilateral forums and a personal attraction for international security matters; he transmitted this interest to the President, who promptly excepted the idea that Brazil was ready to enter the inner sanctum of the United Nations. This issue is notoriously difficult, and Brazil engaged vast resources - human, diplomatic, financial - in lobbying other countries for the purpose of reforming the UN Charter and enlarging its Security Council. The remarkable degree of acceptance of Luis Inácio Lula da Silva by the international media and other world leaders - all of whom, with the exception of George Bush, invited him to the annual G8 meetings - convinced the President that the idea was not only feasible but attainable, despite some opposition from regional partners (most vociferously, Argentina and Mexico).

Brazilian initiatives took various forms. With other developing countries, bilateral debt write-offs were offered to the poorest countries, but sometimes even to oil exporters like Gabon. With the other candidates (Japan, Germany, and India), a G4 was created to support one of the proposals put forward by former UN Secretary General Kofi Annan. Brazil never reached an agreement with two key actors in this process, USA and China, who continuously opposed any substantial reform of the international body. For the sake of its great objective, Brazil assumed a commanding role in the pacification process of Haiti, engaging considerable resources in the task of nation-building that went clearly beyond the country's traditional participation in peacekeeping missions. Also, to enhance Brazil's international presence, the President ordered the opening of permanent embassies in almost all African countries and in all the Latin American states, even in the smallest islands of the Caribbean, all with very limited results in practice. Despite rhetorical support for his pretention, expressed in many bilateral communiqués along his mandate, the President was continuously frustrated.

\section{Alliances with strategic partners (Argentina, China, India, South Africa)}

Luis Inácio Lula da Silva’s diplomacy believed that countries such as Brazil, Argentina, China, South Africa and India not only share common values and the same objectives in the world system, but also have relatively similar social and 
economic characteristics, making them ready to sustain joint projects and efforts at cooperation. IBSA, or the G-3, for instance, was presented as one example of creativity and shared vision between three great multiracial democracies, Brazil, India and South Africa. Having decided to form the group, the three countries struggled hard to find common problems and to establish a list of 'shared solutions', installing as many working groups as possible without regard for the actual differences among. Official rhetoric refers to IBSA as a 'success story', although concrete results, objectively assessed, remain below expectations, providing more promises than real accomplishments.

Argentina is another kind of 'strategic partnership': it was the co-founder of the Southern Cone integration process, with Mercosur at its core, the consolidation of which would require that the co-ordination of macroeconomic policies between the two big associates, as well as a set of joint measures to strengthen the regional bloc, be placed at the center of that endeavor. Instead, Argentina's behavior in Mercosur became a hindrance for Brazilian industrialists, as their exports were subjected to many protectionist restrictions adopted by the Buenos Aires Government, which was still committed to old national practices in trade and industrial policies. The da Silva Government not only tolerated such abuses - contrary to the spirit and to the letter of Mercosur agreements, as well as to WTO-GATT dispositions on safeguards - but also managed to contain the dissatisfaction of Brazilian exporters.

China, for its part, was previously (and uncritically) selected by the President and the PT as a strategic ally, and began to benefit from this position by the declaration, by Brazil, that it filled the requirements of a "market economy", as defined by WTO rules (and thus able to enjoy the bonuses of this recognition in its bilateral trade with Brazil). Brazilian diplomacy misread completely the real will of China in terms of accepting the reform of the UN Charter and the elevation of Brazil to its long sought ambition to become a permanent member of the Security Council. Neither were the Chinese ready to make the huge investments in Brazilian infra-structure that were expected by Luis Inácio Lula da Silva, as they actually regarded Brazil as one more commodity provider among many others.

\section{The dismantling of Mercosur as an unintended consequence}

The 'restructuring', institutional consolidation and enlargement of Mercosur were on Lula's diplomatic menu, as had been explicitly announced since the beginning. According to this priority, total dedication was devoted to the attraction of new partners - Bolivia, Chile, Venezuela, and Ecuador - and facilitating their integration into the bloc (including a waiver on the application of the Common External Tariff, a clear circumvention of the normal discipline inside a customs union, which is what Mercosur pretends to be). Besides the creation of a Mercosur Parliament - without real functions, to be precise - there 
was no real progresses in the fields of trade liberalization and economic opening among member countries. From the designated group of 'candidates', only Hugo Chávez's Venezuela decided to join the bloc, to the consternation of the real democrats and the concerns of the business world. Despite a strong lobby exerted by the da Silva Government in favor of Chávez, the documentation has not yet been concluded, as Paraguay has still to endorse it.

Irrespective of the real setbacks in the commercial areas of Mercosur, it is a fact that Brazil has invested heavily in the project of a stronger Mercosur and its expansion throughout the region. For instance, Brazil proposed, created and financed, at $70 \%$ of its cost, a fund to "correct the imbalances" in the region, a financial scheme equivalent to only a small part, $1 \%$, approximately, of the combined Mercosur member countries' GDPs and that, in fact, duplicates the work of the multilateral banks already operating in the region - the World Bank, the Inter-American Bank and other bodies. Instead of reducing imbalances in the region by market-friendly mechanisms, in line with each country's comparative advantages, governments allocate money to a vast array of projects poorly managed by bureaucrats and incapable of correcting any imbalance between them.

As well as an emphasis on its social and political agenda, Luis Inácio Lula da Silva's big push towards Mercosur's enlargement was to offer it to whichever countries in South America would be willing to join, even at the price of overlooking some of its requirements, simply to accommodate specific countries with strong political motivations. Bolivia, for instance, was offered the chance to enter Mercosur without being liable to the Common External Tariff (which was considered an exaggerated concession by Argentina). Ecuador, along with Bolivia, a member of the Andean Community of Nations (CAN), was also approached, but preferred not to be entangled in any new commercial compromise. Chile, bound to a single tariff, as consolidated in the GATT system, declined from the start to become a full member of Mercosur, taking into account that it benefits from freetrade agreements concluded with each of its hemispheric partners. Colombia and Peru, too, setting aside their CAN membership, opted for free-trade agreements with the United States, a move that pushed Venezuela's Hugo Chávez to denounce the country's membership of CAN and to make a pledge to join Mercosur.

There are two problems with Chávez's political decision to become a full member of Mercosur: on the one hand, since 2006, when that option was chosen, he signed, at the same time, a trilateral pact, with Cuba and Bolivia, creating ALBA, the Bolivarian Alliance of the Americas, a bizarre integration scheme built around state trading, managed cooperation and no free trade at all. On the other hand, Venezuela has never complied with the requirements of Mercosur's customs union - that is, the Common External Tariff and all other regulations to that effect - declaring instead that it's intention was to transform Mercosur from its 'neoliberal' rules to a new political bloc, animated by its own proposals concerning '21st-century socialism'. Even accounting for the political empathy 
demonstrated by the two biggest associates towards Venezuela - in the case of Argentina compounded by the fact that Hugo Chávez was its sole financier after the 2002 moratorium - that was a little too far from the modest capitalist, albeit dirigiste, integration scheme devised by Brazil and Argentina.

\section{Sleeping with a restive neighbor: relations with Argentina}

The most sensible, and relevant, of all bilateral Brazilian relationships, the diplomatic interaction with Argentina, remains in a delicate situation, despite the benign propensity of the da Silva Government to accept almost all restrictions and limitations unilaterally imposed by Buenos Aires on the trade exchanges and reciprocal economic flows. At the beginning the da Silva and Kirchner mandates, in 2003, the excuse for many defensive measures was the profound crisis created by the end of the convertibility exchange regime and the external debt moratorium, followed by a complete standstill in foreign financing for Argentina. In a second stage, bruised by the excessive number of initiatives the Brazilian President was taking to assert Brazil's leadership in the region, Nestor Kirchner hardened Argentinean positions in many negotiating situations, either in Mercosur or in regional matters, and even in multilateral situations, such as Brazilian candidacies in some international organizations (IADB, WTO, and others).

Ego disputes aside, the most important problem was a special safeguards regime that Argentina sought to impose on bilateral trade with Brazil, invoking "structural imbalances" arising from the Brazilian exchange flotation or hidden subsidies on Brazilian exports; "involuntary" export restrictions and other market arrangements were put in place, even against Mercosur rules and WTO dispositions, which the Brazilian President accepted as part of his "diplomacy of generosity" (to the great displeasure of Brazilian industrialists). In other contexts, Brazil was unable (or was not accepted) to mediate the conflict between Argentina and Uruguay over the cellulose plants next to the border. Favorable diplomatic rhetoric apart, Argentina was never very enthusiastic about Brazilian initiatives in the region: the South American Community of Nations, the two inter-regional summits - with Arab and African Countries - the South American Defense Council within Unasur, the Latin American and Caribbean meetings, and some other initiatives. Above all, though, the most contentious issue was Brazil's candidacy to the UNSC seat, followed by its implicit posture as regional leader - two endeavors that affected Argentina self-esteem and moved her to an openly active opposition.

\section{Tropical Man's Burden: Brazil's regional leadership}

One of the most important of Luis Inácio Lula da Silva's diplomatic initiatives, along with the Brazilian candidacy to a permanent seat in the UNSC, is the union of South America as a political entity, free from any interference from the "American empire", and this has always corresponded to a permanent 
project for his party, obviously supported by its Cuban and other Latin American leftist allies. The core of Brazilian regional diplomacy, under the direct inspiration of Itamaraty's Secretary-General, was strongly directed towards this ambitious objective, with partial successes in various aspects.

The economic aspect of the project - the political implosion of the American proposal of a FTAA, followed by the creation of a South American Free Trade Area - was only half-achieved: the abandonment of a hemispheric trade liberalization scheme. Brazilian initiatives towards creating its own economic space in the region were downsized to a mosaic of bilateral agreements within the framework of a Latin American Integration Association that failed to promote expanded exchanges or to effectively integrate the economies of the countries. The modest opening of the Brazilian economy in favor of its neighbors curtailed the Brazilian's grand vision for the continent.

The political components of the project remained too vague to really unite ten South American States that harbor different conceptions, sometimes opposed to each other, about political and economic integration. Unhappily for the Brazilian project, the fact is that South America became less, not more, integrated during Luis Inácio Lula da Silva's tenure, and the reason has little to do with external crises or military dictatorship. Indeed, democracy has progressed in the region, but political instability remains a crucial factor that explains the differing concepts of integration, and some of the regional crises. By most accounts, Bolivarianism and indigenism, arising in Andean countries, have rendered those polities more instable, socially and politically, and prone to old conceptions of integration, marked by State-led economic policies, nationalization and a less relevant role for trade and finance, compared to social and political issues, all of which was completely at odds with a market-led integration, such as that practiced in Mercosur.

In addition, the exercise in 'regional leadership', as tentatively tried by Luis Inácio Lula da Silva’s diplomacy, was not well received; in fact, it had never been welcomed in the past, one more reason for professional diplomacy making a taboo of this difficult concept. Tempted by his warm reception in the world press and among many political leaders, Lula believed that the time was ripe for Brazil to assume a more assertive posture based on political dialogue, Brazilian financing of development projects and a tentative measure to coordinate positions in regional or multilateral negotiations.

Being the largest economy in the region, Brazil exerts a natural attraction on neighboring countries, but that has not been enough to overcome old suspicions about its quasi-imperialistic behavior in South America, or its supposed desire to impose its own domination over other countries, replicating, albeit in a less arrogant manner, American imperial tutelage. In fact, Brazil has never exerted any guardianship over the region, but the multiplication of initiatives could be seen as devoid of vested interests. That could be one of the reasons for Andean countries not accepting the offer by Brazilian diplomacy to set up a secretariat for 
the newly-created South American Community of Nations, an entity that was replaced, one year later by the Hugo Chávez-sponsored Union of the Nations of South America (Unasur), with its headquarters in Quito.

The da Silva Government also failed to provide an adequate substitute to a scheme devised by Cardoso's administration for the infrastructure projects in South America. The Initiative for the Integration of South America (IIRSA), created in 2000, never advanced from its stage of portfolio projects - prepared by the INTAL-IADB - to transform them into concrete undertakings capable of mobilizing private and official financial resources to deal with the multiple needs in the region in terms of energy, communications, and major engineering projects (notably in transport). As regards investments and other market opportunities, the successful implosion of the FTAA by Brazilian diplomacy (with a little help from Argentina and Venezuela) may have thrown some countries into the arms of the USA, as Brazil is not really a powerful replacement solution for economies looking for big flows of direct investment and access to larger markets, at least not those of the size of the United States; in the same move, Brazil ended up with less market access and reduced preferences in its neighbors' markets.

\section{A bridge too far: multilateral and regional trade negotiations}

Access to new markets through multilateral trade negotiations, with small concessions in new areas - like investments, intellectual property and services - but also in industrial tariffs, have always been a chasse gardée for Itamaraty, preserved from intrusions by other government agencies. This domestic hegemony was somewhat contested during Lula's government - especially by Brazilian agricultural producers competing in world markets, but also other sectors - because of the extreme politicization of those economic issues practiced since the beginning. Under the slogan of creating a 'new geography for world trade', Itamaraty aligned Brazil with other developing countries - always with the aim of presenting a united front against rich countries - disregarding the fact that some of those countries (including China and India, two of its strongest 'allies') possessed in reality interests directly opposed to Brazil's aim in dismantling agriculture protectionism and high subsidies in the area.

The Commercial G20, created at the Cancun ministerial meeting of the WTO (2003), was presented as a strong expression of Brazilian leadership in trade negotiations, and as an 'alternative' to old negotiating schemes, but its internal contradictions quickly became apparent in subsequent phases and the group was not capable of overcoming different interests among its members to present a united front in some crucial issues related to it. For all practical purposes, the offensive stance of Brazil in those matters was rendered as defensive as the Chinese or Indian positions, including in non-agricultural market access (NAMA) and in services, in a time when Brazilian farmers, and even many industrialists, were disposed to advance further. 
In the same areas, and in other negotiating instances - such as in the framework of trade talks between Mercosur and the EU - less ambitious positions or a limited disposition to make concessions in industrial tariffs from partners like Argentina (but the same applies to India and some other developing countries) curtailed the possibility for Brazil to reach an acceptable agreement with other developing countries, thus opening new markets for Brazilian products. The preferential alliances devised by Itamaraty with other developing countries which included 'social concerns' and 'interests of less competitive agriculture', or 'family farms' - added to the hindrances that had been self-inflicted for political reasons, in addition to the fact that the great expansion for Brazilian exports in the farming sector is essentially concentrated in the emerging markets, not in rich countries. In this sense, the 'South-South' policy and the 'new geography of trade', with all their political bias, were in contradiction to Brazilian national interests and the country's natural competitive advantages. Asian countries, for instance, have for a long time been practicing the 'new geography' in expanding their exports to rich countries in the West.

\section{Dragons, elephants and other fauna: Brazil's presence in the world}

China was designated an 'ally', or 'strategic partner' even before Luis Inácio Lula da Silva's coming to power, as he made a political visit to that country in 2001, and was received with the honors due to an important political leader. At that time, many of the PT leaders still held the erroneous belief that China was a socialist economy and a country interested in constituting a 'common front' against the arrogant rich countries and Western 'imperialism'. When he came to power, Luis Inácio Lula da Silva started to put in practice his unilaterally conceived 'Chinese policy', which consisted of great expectations concerning major investments in Brazil and, especially, a strong political relationship by which both countries were to influence a big change in world power, reducing the spaces for 'hegemony' in international politics - a concept used by the Chinese, by the way.

The Brazilian's diplomacy imagined that, by conceding to China the status of a 'market economy', as requested by the Chinese leadership, it would be possible to capture large-scale investments and technological cooperation, as well as the most prized reward sought by the president: China's support for the Brazilian aspiration to a seat in the UNSC. In other occasions - during reciprocal state visits - the President even considered the idea of a free-trade agreement between China and Mercosur, and offered the possibility of replace the payment system in bilateral trade, starting to use local currencies instead of dollars. Both measures were clearly in favor of Chinese interests and, thanks to the opposition from entrepreneurs - alarmed by the destructive potential of low-cost Chinese competition - and from some more vigilant bureaucrats in the Central Bank, they were not implemented at all, despite being proposed by the President himself (probably out of naïveté or simple ignorance of economic matters). 
China never committed itself to supporting Brazil in its quest for the UNSC seat and has always acted in its own self-interest, even on strictly bilateral matters; it did not hesitate, for instance, to impose a trade embargo on the arrival of a Brazilian cargo of soy beans invoking sanitary measures, when it was simply pushing down the prices, and this on the eve of one of Luis Inácio Lula da Silva's official visits to China. In other contexts China makes very clear that it wants to keep for itself the decision on the desirable pattern for bilateral relations, including matters pertaining to private investment and a common multilateral agenda (either in BRIC meetings, or elsewhere).

The creation of the informal group called BRIC, comprising Brazil, China, India and Russia, has the latter country as the main partner with Brazil in the endeavor that looks more at political aims than economic objectives, despite the fact that the proposal by an investment economist takes its legitimacy from their economic importance for the future world economy. The new acronym has attracted a lot of publicity but it remains to be seen if the group has, effectively, coherent, sound and feasible proposals for global governance, justifying its claim to be an alternative to the traditional G7-G8 group. In the same way, the decision to strengthen links with new and old partners, in other continents, fits Luis Inácio Lula da Silva's intention to diversify the options available for Brazilian exports, other sources for sophisticated technology - with France, for instance - and to achieve a balance of commercial objectives and attain a leading political role for the country in the world (as in the summits organized with Arab and African countries together with South American neighbors of Brazil).

A resident diplomatic representation was established in Ramallah and Luis Inácio Lula da Silva tried to insert himself in the complicated chessboard of Middle East conflicts, offering to mediate a 'peace' between Israelis and Palestinians on the basis of 'sincere dialogue', which, of course, arrived at nothing. New attempts at bona fide diplomacy were made in connection with the troubled negotiations between the great powers and Iran, over that country's covert activities regarding its nuclear program, only to characterize Brazil's President as a friend of the controversial figure of Ahmadinejad. Brazil's too lenient posture regarding human rights violations around the world, together with Luis Inácio Lula da Silva's indulgence towards dictators like Fidel Castro, have tarnished the good record previously held by Brazil.

There is no doubt that Brazil has become an important broker in many instances on the international agenda, even if some ambiguities remain over specific points of the political aspect of the PT's external policy (human rights and democracy being the most visible, but also non-proliferation and environment). Luis Inácio Lula da Silva had the opportunity to engage in dialogue at the same time with capitalists in Davos and the dreamers of the World Social Forum, but many in his immediate surroundings exhibited a clear anti-American stance, as was revealed, for instance, in the cases of Honduras and Venezuela. The President's 
negative appraisals of 'neoliberalism' and 'Wall Street speculators' have more to do with old-fashioned leftist postures than with the diplomatic seriousness required from an aspiring emerging power. At the beginning of his mandate, Luis Inácio Lula da Silva attempted to 'sell' to other Latin American countries a replacement of the 'Washington Consensus', by means of a so-called 'Buenos Aires Consensus', a fragile set of fragile rules about welfare policies. At the end of his mandate, had become a strong critic of the current international system, probably frustrated by the unwillingness of great powers to reform the UNO Charter and accept Brazil as one of the 'more equals'.

\section{Luis Inácio Lula da Silva's heritage: Brazilian diplomacy's new clothes}

The October 2010 presidential elections in Brazil provide the opportunity to change many things in foreign policy, if there is a social-democratic victory probably more in the region, and specifically in connection with Mercosur, than in Brazil's world role - or, otherwise, a new government can maintain, roughly speaking, the same lines in diplomacy as followed during the last eight years of the da Silva administration. Indeed, the PT's foreign policy, though not consensual, is widely accepted by many sectors of public opinion, mainly in academia and left-wing parties and movements. It would be more of the same, except for the lack of a colorful president, who has represented Brazil abroad in a lively manner in times of great changes in world scenarios.

Some positions will probably not change, of course: the self-characterization of Brazil as a developing country, its pretension to be a speaker on behalf of other poor countries seeking a new economic order, with more justice and fairness being shown towards those countries, the reduction of the inequalities and imbalances that still divide the world, the democratization of international politics - with Brazil standing yet again as a candidate for a permanent seat on the UNSC and many other requests of this nature. Strong action against hunger, poverty and injustices will continue to be high in the agenda, as well as the defense of sovereignty and states' policies directed to social development.

South America - and with the PT, Latin America - will be maintained as the most relevant priority of Brazilian foreign policy, but in the case of a socialdemocratic win, exclusive 'South-South' policies will probably be scaled down within the ranks of Itamaraty, in favor of a more balanced view of cooperation and a more pragmatic position regarding commercial policies and human rights issues. Multilateralism in economic and political careers will keep the same importance as always and Itamaraty will regain some of the spaces it lost to a very activist presidential palace in the last eight years. There will probably be less presidential diplomacy, and more 'normal', professional diplomacy, with less travel and visits both abroad and to Brazil.

Changes in or of style and different emphases apart, Brazil will undoubtedly retain the growing economic and political importance it attained during Luis 
Inácio Lula da Silva's administration. The new view of Brazil held by foreign countries has objective grounds: the preservation of economic stability and the steady, albeit modest, growth rates exhibited by Brazilian economy that its diplomacy has been able to capitalize upon. China, the current engine of the world economy became the main Brazil's trading partner in the last year of Luis Inácio Lula da Silva's mandate, but it was China that that has contributed most to Brazilian growth, a growth much more based on the value given to its commodities than on the diversification and expansion of exported manufactures. In fact, economic growth in Brazil is perhaps becoming too dependent on China, as was the case in the past with the Brazilian-American relationship. However, in the context of the BRIC countries, Brazil has shown the worst growth rate of the four nations, and has not lost its relative share of the world GDP or the intensity of its participation in international trade.

Thus, despite Luis Inácio Lula da Silva's satisfaction with the greater presence of Brazil in the world, which allows him to enhance his own leading role in building that position, it would not be wrong to say that this new role derives much more from a hyperactive diplomacy, based on the strong promotion of the President himself, than from a real transformation in the objective position of Brazil in the economic and political scenarios. Growth in nominal GDP as compared to other countries is, at least in some measure, the result of the currency's appreciation against the dollar; in the same way, growth in exports reflects the growing demand from dynamic countries for Brazilian commodities; there is also the expansion of domestic credit for consumption, even at the risk of a bubble arising from excessive debt contracted by individuals and families. On a similar topic, the economic stability granted since Cardoso's administration, and rightfully preserved by da Silva, together with the size of the domestic market and Brazilian connections within the framework of Mercosur, are responsible for the huge amounts of foreign direct investments that have been attracted since then. This relatively benign scenario will probably be maintained for the next few years, depending on the main markets for Brazilian products (today tending towards China) and on external credits from financial markets.

An overall evaluation of Luis Inácio Lula da Silva's diplomacy should be able to recognize its ability to project a dynamic image of Brazil worldwide, helping to make the country a fully-fledged actor in the forefront of international diplomacy. Brazil is certainly present in many of the most important discussion bodies dealing with economic and political issues in the world agenda. Not surprisingly, the personal figure of da Silva is even more present than the country, which confirms the real success of his diplomacy in projecting his own image as the personification of Brazil.

In terms of its own development though, Brazil is still an emerging country, with many social deficiencies, economic imbalances, uneven regional progress, and an extremely problematic public education system; its state institutions and 
corruption levels are much more akin to the standard patterns already familiar in developing countries than with the advanced economies that Brazil is struggling to imitate. Incidentally, it is worth noting that Brazil could be a full member of the OECD, as it has received 10 open invitation in recent years to consider becoming associated with that organization; it was only for ideological and political reasons that Luis Inácio Lula da Silva’s diplomacy choose to stand aside. Even taking into account some economic challenges arising from such a decision, OECD patterns in economic policy and governance would help Brazil to modernize its structures and improve the overall performance of its public policies.

Indeed, the main challenges for Brazil in the years ahead are entirely internal, with few, or none, deriving from external factors. Domestic problems are mainly to blame for the modest role still characterizing Brazil's world presence; an ambitious set of governance reforms - the taxation system, labor legislation, political and administrative reforms, and an educational revolution - most of them in line with OECD patterns, should contribute to the international aggrandizement of Brazil. Those tasks will presumably depend on a less ideological type of governance and on a new kind of diplomacy, open-minded and market-friendly. This task is for a post-da Silva government.

Received August 14, 2010 Accepted November 18, 2010

\begin{abstract}
Critical assessment of Luis Inácio Lula da Silva's diplomacy, which departed from the previous patterns of the Brazilian Foreign Service, to align itself with the political conceptions of the Workers' Party. This diplomacy has neither consolidated the position of Brazil as a regional leader, nor attained its declared goal of inserting Brazil into the United Nations Security Council, although it has reinforced Brazil's image in the international scenarios; but this was achieved much more through the personal activism of the President himself, than through normal diplomatic work.
\end{abstract}

\title{
Resumo
}

Avaliação crítica da diplomacia do governo Lula, que abandonou os padrões tradicionais do Itamaraty para alinhar-se com as concepções políticas do Partido dos Trabalhadores. Essa diplomacia não conseguiu consolidar a posição do Brasil como líder regional, nem logrou o objetivo declarado de colocar o país no Conselho de Segurança das Nações Unidas, muito embora tenha reforçado a imagem do Brasil no cenário internacional; mas isso foi alcançado mais por meio do ativismo do próprio presidente, do que pelo trabalho diplomático normal.

Key-words: Brazil, diplomacy, Lula government, regional leadership, global presence.

Palavras-chave: Brasil, diplomacia, governo Lula, liderança regional, presença global. 